\title{
IMPACT OF LINEAR THERMAL BRIDGES ON THERMAL TRANSMITTANCE OF RENOVATED APARTMENT BUILDINGS
}

\author{
Simo ILOMETS, Kalle KUUSK, Leena PAAP, Endrik ARUMÄGI, Targo KALAMEES \\ Faculty of Civil Engineering, Department of Structural Design, Tallinn University of Technology, \\ Ehitajate tee 5, 19086 Tallinn, Estonia
}

Received 12 May 2014; accepted 16 Jul 2014

\begin{abstract}
Renovation of old apartment buildings is a topic of current research interest throughout the Eastern Europe region where similar typology is derived from the period of 1960-1990. Thermal bridges, essential components of the transmission heat loss of a building, have to be properly evaluated in the energy audit during current state-of-the-art situation as well as in the comparison of renovation solutions. Resulting from field measurements and calculations, we propose linear thermal transmittances $\Psi$ of thermal bridges for four types of apartment buildings: prefabricated concrete large panel element, brick, wood (log), and autoclaved aerated concrete. Our results show that thermal bridges contribute $23 \%$ of the total transmission heat loss of a building envelope before renovation. After renovation thermal bridges account for only $10 \%$ if windows are repositioned into additional external thermal insulation and balconies are rebuilt as best practice. Inversely, impact of the thermal bridges might be up to $34 \%$, depending on the wall insulation thickness. We have also found that the relative percentage of thermal bridges after renovation increases and the negative impact of the thermal bridges of certain junctions cannot be compensated with thicker wall insulation. Results obtained in this paper are useful for energy audits.
\end{abstract}

Keywords: thermal bridge, apartment building, large-panel, brick, wood, AAC, linear thermal transmittance, transmission heat loss, need for renovation.

\section{Introduction}

The thermal bridge is a part of the building envelope where the otherwise uniform thermal transmittance is locally significantly larger. The European Directive on the Energy Performance of Buildings (EPBD 2010) states that the methodology for calculating the energy performance of buildings should also take into account thermal bridges. All EU Member States plus Norway consider thermal bridges in the energy performance assessment of new buildings, but to a lesser extent in the assessment of existing buildings that undergo major renovation (Erhorn et al. 2010). From seven essential requirements set in the Construction Products Regulation (EU) No 305/2011 (2011), thermal bridges influence the requirements for "hygiene, health and the environment" and "energy economy and heat retention".

The share of thermal bridges in the transmission heat loss depends on the climate and construction. In warm France and Greece the influence of thermal bridges is in a range of 5-35\% (Déqué et al. 2001; Theodosiou, Papadopoulos 2008). In cold Sweden, the impact of thermal bridges may be accounted for by the increasing heat transfer between $20 \%$ and $38 \%$ for precast concrete sandwich walls and between $12 \%$ and $26 \%$ for wooden frame walls (Berggren, Wall 2013) in terms of internal dimensions of the building envelope.

The better the insulation of the building envelope, the larger the relative contribution of thermal bridges on the overall transmission heat loss of the building and the more important it is to develop improved constructional details (Janssens et al. 2007). Comprehensive research about evaluating thermal bridges by a quantitative approach with a new method is introduced in Asdrubali et al. (2012).

There are many methods to determine linear thermal transmittance of thermal bridges: numerical calculations (typical accuracy $\pm 5 \%$ ), thermal bridge catalogues $( \pm 20 \%)$, manual calculations $( \pm 20 \%)$, and default values (0-50\%) (EN ISO 13789:2008; EN ISO 14683:2008).

Linear thermal transmittance values of thermal bridges for new buildings are to be calculated by the designer or can be commonly taken from a standard EN ISO 14683:2008 (2008), database or catalogue (Tilmans, Orshoven 2009). Regression equations for thermal bridges of typical junctions are presented in Capozzoli et al. (2013) and Ben Larbi (2005). Thermal bridges were analysed in a guarded hot box testing facility by Martin et al. (2012a) who demonstrated the methodology

Corresponding author: Simo Ilomets

E-mail:simo.ilomets@ttu.ee 
(Martin et al. 2012b) to calculate an equivalent wall, which has the same dynamic thermal behaviour as the thermal bridge. A pragmatic approach was used in Roels et al. (2011) to incorporate the effect of thermal bridging within the EPBD (2010) regulation. It is stated that thermal bridges are a crucial point in the energy analysis of the building envelope. Most of the studies are applicable to the design of new buildings rather than to energy renovation of old apartment buildings.

Renovation of an old building envelope is important because it offers a huge (60 Mtoe by 2030 for the EU28) potential for energy savings (Lechtenböhmer, Schüring 2010). To simplify design, which is anyhow undervalued and derogated concerning time and money, a simplified approach to thermal bridges would be preferable in older buildings under major renovation.

Renovation/modernisation of old apartment buildings is a topic of current interest in the whole Eastern Europe region with similar buildings. In Lithuania, as reported in Biekša et al. (2011), the current shape and tendencies of multi-apartment building renovation are far from completion and further improvement and recommendations are needed. Almost a decade ago, Zavadskas et al. (2004) developed a method with a multi-criteria approach in order to analyse renovation scenarios of old apartment buildings. Recently they have proposed a more general but still a multi-criteria approach for all construction works (Zavadskas et al. 2014). A relevant factor to be considered is the form of ownership in the Baltic States that differs from most of Europe - each apartment has a different owner.

Before renovation, the proper evaluation of the technical condition and energy performance of a building with possible energy savings is essential. A relevant approach is presented in Ignatavičius et al. (2007) in the context of case-study analysis and results. To select energy saving measures properly and to evaluate their efficiency, the consumed and calculated heat amounts "before" and "after" the renovation should be divided into components (Čiuprinskas, Martinaitis 2003). Further, linear thermal transmittance of the thermal bridges should be taken into account when calculating energy consumption of a building.

Many older apartment buildings in Eastern Europe were constructed according to a standard design with similar architectural and constructional typology, including typical thermal bridges. Therefore, for typical apartment building series, similar values of the linear thermal transmittance of thermal bridges may be used. This can help energy auditors and designers to choose a proper quantity of the thermal bridges in order to improve energy calculations. Regarding to inhabitants and owners of older apartment buildings, the cost of renovation design documentation is usually critical, "ready to use" values of linear thermal transmittances can reduce the design time, harmonise the quality and lower the cost.
This paper evaluates the impact of thermal bridges in the transmission heat loss. Different levels of building envelope insulation were analysed for apartment buildings composed with prefabricated reinforced concrete large-panel elements, bricks, wood and autoclaved aerated concrete large-blocks, mostly built during the constructional wave between 1960 and 1990. We have calculated the true impact of thermal bridges in the transmission heat loss of a building envelope before and after renovation. Numerical values of proposed linear thermal transmittances are useful for energy audits.

\section{Methods}

\subsection{Buildings studied}

Based on the main construction material, four different building types were analysed: prefabricated reinforced concrete large-panel element (hereafter: concrete element) (13 example buildings), brick (15 buildings), wood (log 20 buildings), and autoclaved aerated concrete (AAC) large-blocks (1 building). Typical buildings with different construction, service systems, ages and number of storeys were selected. External walls of concrete element buildings (Fig. 1 left) are composed of two layers of reinforced concrete $(50-130 \mathrm{~mm}$ inner load-bearing layer and $50-80 \mathrm{~mm}$ outer core) and $100-150 \mathrm{~mm}$ thick insulation layer in between (fibrolite, mineral wool, phenolic foam or expanded polystyrene). Different elements are welded and concreted together in-situ. Thermal transmittance of walls varies between $U=0.5-1.0 \mathrm{~W} /\left(\mathrm{m}^{2} \cdot \mathrm{K}\right)$ and that of roofs $0.7-1.0 \mathrm{~W} /\left(\mathrm{m}^{2} \cdot \mathrm{K}\right)$. Thickness of the inner load-bearing layer in brick buildings (Fig. 1 right) is 250 $630 \mathrm{~mm}$ (typically calcium silicate brick), $60-120 \mathrm{~mm}$ mineral wool thermal insulation, and $120 \mathrm{~mm}$ of external layer (calcium silicate or ceramic brick). Also, thick brick walls without insulation material were analysed. Thermal transmittance of brick walls varies between $0.5-1.2 \mathrm{~W} /$ $\left(\mathrm{m}^{2} \cdot \mathrm{K}\right)$ and that of roofs $0.7-1.0 \mathrm{~W} /\left(\mathrm{m}^{2} \cdot \mathrm{K}\right)$. In general, slabs on the ground and cellar ceilings are uninsulated.

The two- and three-storeyed wooden apartment buildings studied were built in the first half of the $20^{\text {th }}$ century (Fig. 2 left). The external wall is built with a horizontal or vertical load-bearing log wall with a thickness of 120-180 mm. Inserted ceilings are usually built from wooden beams, whereby cellar ceilings can be also made of concrete on steel beams. Thermal transmittance
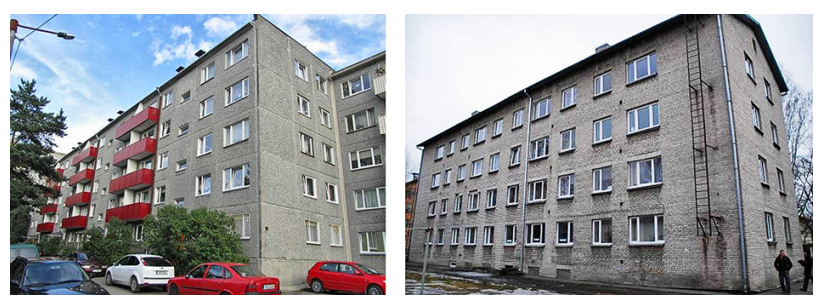

Fig. 1. Typical prefabricated reinforced concrete large-panel element apartment building (left) and brick apartment building (right) 


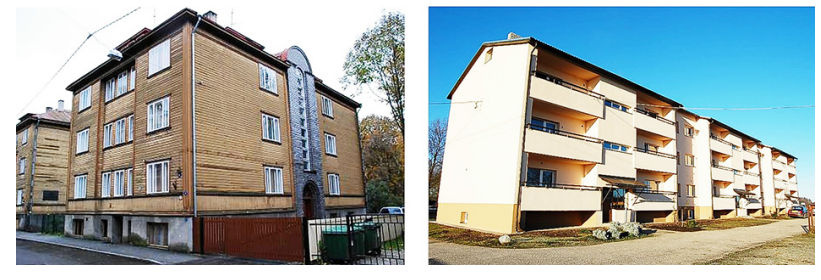

Fig. 2. Typical wooden apartment building (left) and autoclaved aerated concrete large-block building (right)

of solid wooden walls varies between $U=0.5-0.9 \mathrm{~W} /$ $\left(\mathrm{m}^{2} \cdot \mathrm{K}\right)$. Attics and cellars are generally unheated, and the thermal transmittance of those inserted ceilings separating heated space is $\sim 0.5 \mathrm{~W} /\left(\mathrm{m}^{2} \cdot \mathrm{K}\right)$.

Apartment buildings composed of autoclaved aerated concrete (AAC) are mainly (Fig. 2 right) composed of largeblocks that have lime or oil shale ash as a binding agent. Visually similar to some types of brick apartment buildings, these buildings generally have $2-5$ storeys. Thermal transmittance of $300 \mathrm{~mm}$ solid walls (density $\rho \sim 800-1000 \mathrm{~kg} / \mathrm{m}^{3}$ ) varies between $U=0.6-1.1 \mathrm{~W} /\left(\mathrm{m}^{2} \cdot \mathrm{K}\right)$ and that of pitched or flat roofs $1.0-1.5 \mathrm{~W} /\left(\mathrm{m}^{2} \cdot \mathrm{K}\right)$.

\subsection{Calculation methods}

Thermal performance of typical thermal bridges was analysed with the two-dimensional (2D) steady-state finite element heat-transfer simulation program THERM 6.0 developed by the Lawrence Berkeley National Laboratory and calibrated according to the EN ISO 10211:2007 (2007) standard. The linear thermal transmittance of the thermal bridges $\Psi, \mathrm{W} /(\mathrm{m} \cdot \mathrm{K})$ was calculated by Eqn (1):

$$
\Psi=L_{2 D}-\sum_{j=1}^{N_{j}} U_{j} \cdot l_{j}, \mathrm{~W} /(\mathrm{m} \cdot \mathrm{K}),
$$

where $L_{2 D}$ is the thermal coupling coefficient obtained from the $2 \mathrm{D}$ calculation of the component separating the two environments being considered, $\mathrm{W} /(\mathrm{m} \cdot \mathrm{K}) ; U_{j}$ is the thermal transmittance of the 1D component $j$ separating the two environments being considered, $\mathrm{W} /\left(\mathrm{m}^{2} \cdot \mathrm{K}\right) ; l_{j}$ is the length over which the value $U_{j}$ applies, m. Length $L_{2 D}$ is equal to $\sum l_{j}$. Overall internal dimensions of the external envelope according to EN ISO 13789:2008 (2008) was used in the calculations.

In the calculations of linear thermal transmittance, average values of internal surface resistance from the EN ISO 6946:2007 (2007) standard were used: for roof $R_{\mathrm{si}} 0.10 \mathrm{~m}^{2} \mathrm{~K} / \mathrm{W}$, for wall $R_{\mathrm{si}} 0.13 \mathrm{~m}^{2} \mathrm{~K} / \mathrm{W}$, for floor $R_{\mathrm{si}}$ $0.17 \mathrm{~m}^{2} \mathrm{~K} / \mathrm{W}$. Thermal resistance $R_{\mathrm{se}} 0.04 \mathrm{~m}^{2} \mathrm{~K} / \mathrm{W}$ was used for all external surfaces. Thermal conductivities of the materials used in the calculations are presented in Table 1.

Linear thermal transmittances were calculated for four different building types as original and additionally insulated building envelopes: $+100 \mathrm{~mm},+150 \mathrm{~mm}$, $+200 \mathrm{~mm}$ and $+300 \mathrm{~mm}$ additional external thermal insulation with the thermal conductivity $\lambda=0.04 \mathrm{~W} /(\mathrm{m} \cdot \mathrm{K})$.
Table 1 . Thermal conductivity $\lambda, \mathrm{W} /(\mathrm{m} \cdot \mathrm{K})$ of the materials used

\begin{tabular}{lc}
\hline \multicolumn{1}{c}{ Material } & $\begin{array}{c}\text { Thermal } \\
\text { conductivity } \\
\lambda, \mathrm{W} /(\mathrm{m} \cdot \mathrm{K})\end{array}$ \\
\hline Polyurethane foam (PU) & 0.024 \\
Additional insulation (mineral wool/ EPS) & 0.040 \\
Phenolic foam (based on phenolic resin) & 0.043 \\
Mineral wool of exist. building envelope & 0.070 \\
Rubber foam, mastics & 0.10 \\
Sawdust & 0.10 \\
Wood & 0.13 \\
Fibrolite (chip cement board) & 0.16 \\
Autoclaved aerated concrete (AAC) & 0.23 \\
Dry sand & 0.25 \\
Expanded clay concrete & 0.30 \\
Hollow calcium silicate masonry & 0.70 \\
Ceramic brick masonry & 0.70 \\
Calcium silicate brick masonry & 0.90 \\
Lime-cement mortar & 1.0 \\
Concrete & 2.0 \\
\hline
\end{tabular}

Transmission heat loss (also heat flow rate, W) of a building envelope consists of several components - thermal transmittance $U$, linear thermal transmittance $\Psi$ and point thermal bridges $\chi$. Thermal transmittance can be also presented as an overall reduced (in literature: also "effective") thermal transmittance of a wall $U_{\text {red }}$ that consists of heat transfer through the 1D opaque wall (excluding windows) and of heat transfer through the 2D thermal bridges divided by the wall area according to Eqn (2):

$U_{\text {red }}=\frac{H}{A}=U+\frac{\sum \Psi_{j} \cdot l_{j}+\sum \chi_{j} \cdot n_{j}}{A}, \mathrm{~W} /\left(\mathrm{m}^{2} \cdot \mathrm{K}\right)$,

where $H$ is a specific heat transfer, $\mathrm{W} / \mathrm{K} ; A$ is the area of $1 \mathrm{D}$ wall, $\mathrm{m}^{2} ; U$ is the thermal transmittance of the $1 \mathrm{D}$ wall, $\mathrm{W} /\left(\mathrm{m}^{2} \cdot \mathrm{K}\right) ; \Psi_{j}$ is the linear thermal transmittance of the thermal bridge, $\mathrm{W} /(\mathrm{m} \cdot \mathrm{K}) ; l_{j}$ is the length of the thermal bridge, $\mathrm{m} ; \chi_{j}$ is the point thermal transmittance of the thermal bridge, $\mathrm{W} / \mathrm{K} ; n$ is the number of point thermal bridges. Point thermal bridges are not taken into account in this paper.

\subsection{Field measurement methods}

Buildings were surveyed first by assessing the technical condition and secondly by using infrared thermography. Original design drawings were collected (see Fig. 3) and inhabitants and operators interviewed. Surface temperatures were measured to enable the comparison of calculation results and to increase the reliability of the calculated linear thermal transmittances.

To determine the thermal bridges and their distribution, measurements with an infrared image camera FLIR ThermaCam E320 (thermal sensitivity of $0.1{ }^{\circ} \mathrm{C}$, measurement range from $-20{ }^{\circ} \mathrm{C}$ to $+500{ }^{\circ} \mathrm{C}$ ) were conducted 


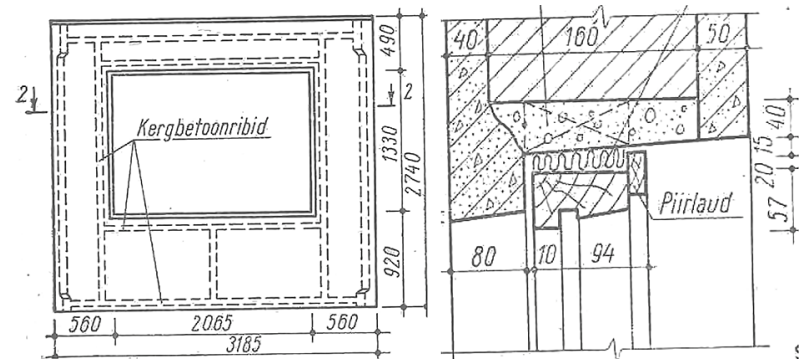

Fig. 3. Original design drawings of reinforced concrete largepanel element building - external wall element (left) and external wall/ window junction (right)

in 49 buildings. Measurements were done according to the standard EN 13187:2001 (2001) during the winter while the temperature difference between the indoor and outdoor air was at least $20 \mathrm{~K}$. For the emissivity $\varepsilon$ of the surface materials, data from the infrared literature and measurements made by FLIR Systems (2006) were used. Air pressure difference was consciously not created, but it existed to some extent due to wind and different densities of the indoor and outdoor air.

\section{Results}

\subsection{Measurement results}

Field measurements in concrete element buildings showed that the critical thermal bridges are located in:

- horizontal and vertical joints between external wall elements, see Figure 4 (top);

- junctions of the external wall and the balcony slab, see Figure 4 (top);

- junctions of the external wall (especially end sides) and the flat roof, see Figure 4 (top and bottom);
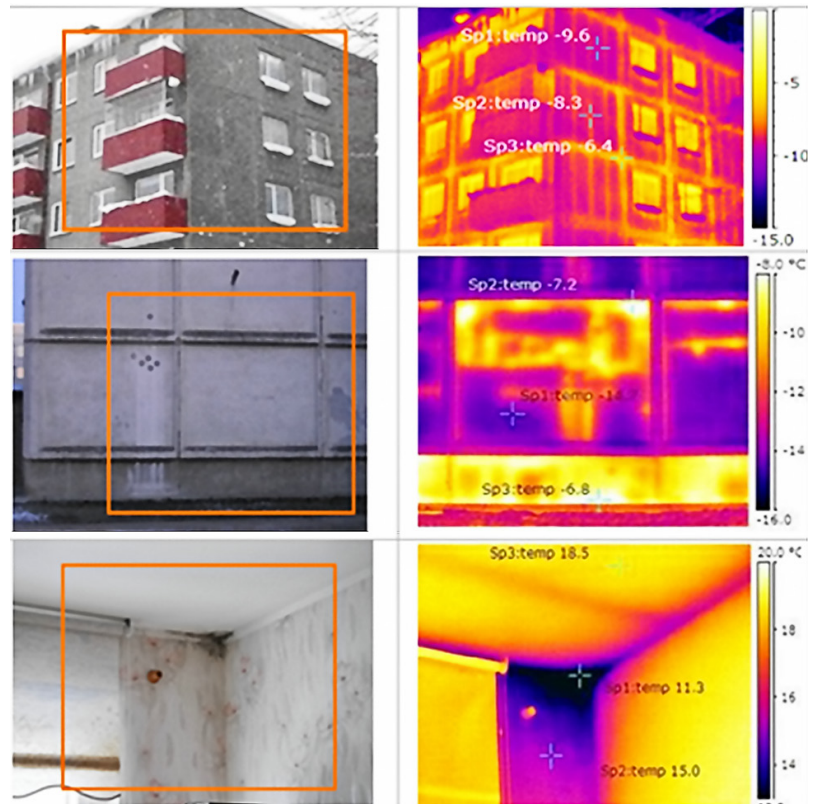

Fig. 4. Thermal bridges of a concrete element apartment building from outside (top and middle) and from inside (bottom)

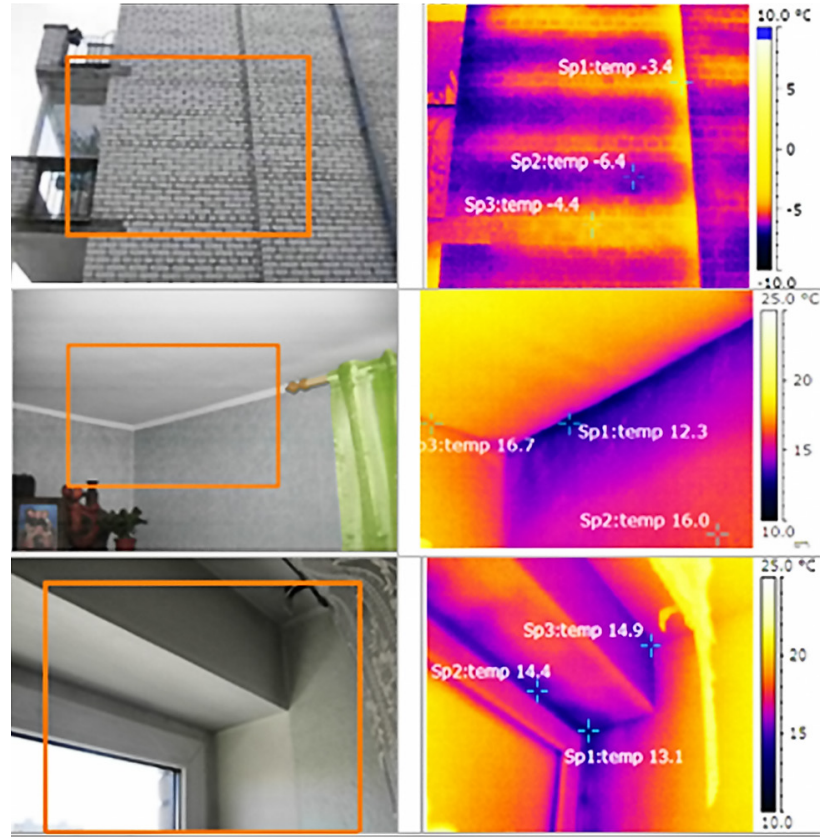

Fig. 5. Thermal bridges of a brick building from outside (top) and from inside (middle and bottom)

- bonds of element's inner and outer layers of the external walls, see Figure 4 (top);

- foundation wall elements, see Figure 4 (middle);

- junction of the external wall and the window/door, see Figure 4 (top).

Also, wall elements with missing or poor insulation existed, see Figure 4 (middle). In the worst cases, mould growth was visually detected on the internal surface of the thermal bridges, see Figure 4 (bottom).

Field measurements in brick apartment are presented in Figure 5.

Field measurements in brick buildings showed that the thermal bridges are located in:

- junctions of the external wall and the flat or pitched roof;

- junctions of the external wall and the balcony or loggia slab and wall;

- junctions of the external wall and the window/ door, see Figure 5 (bottom);

- junction between the foundation wall elements and the external wall;

- junctions of the external wall/inserted ceiling, see Figure 5 (middle);

- bonding bricks, see Figure 5 (top).

Field measurements in the old wooden (log) apartment buildings showed that the most critical thermal bridge is located at the junction of the external wall and the cellar ceiling. This is caused by the large thermal transmittance of limestone foundation that the log wall lies on. Since leaky 2-frame windows were typically used in wooden buildings, low surface temperatures caused by air leakage rather than by the thermal bridge were determined around the windows. 
Table 2. Calculated linear thermal transmittances $\Psi_{\mathrm{oi}}, \mathrm{W} /(\mathrm{m} \cdot \mathrm{K})$ of various external wall junctions for different building types by using overall internal dimensions of a building envelope. Upper row is for pre-renovation situation and lower row for postrenovation situation with $+200 \mathrm{~mm}$ thermal insulation as an example. Values are given as a range, and at substantial variation, with a third value in between as the most probable (in brackets)

\begin{tabular}{|c|c|c|c|c|c|}
\hline \multirow{2}{*}{ Junction of external wall } & \multirow{2}{*}{$\begin{array}{c}\text { Original wall/ } \\
+200 \mathrm{~mm} \text { insulation }\end{array}$} & \multicolumn{4}{|c|}{ Calculated linear thermal transmittances $\Psi, \mathrm{W} /(\mathrm{m} \cdot \mathrm{K})$} \\
\hline & & $\begin{array}{l}\text { Concrete element } \\
\text { building: }\end{array}$ & $\begin{array}{c}\text { Brick } \\
\text { building: }\end{array}$ & $\begin{array}{l}\text { Wooden }(\log ) \\
\text { building: }\end{array}$ & $\begin{array}{c}\text { AAC } \\
\text { (building): }\end{array}$ \\
\hline $\begin{array}{l}\text { External corner of } \\
\text { external walls }\end{array}$ & $\begin{array}{c}\text { Original/ } \\
+200 \mathrm{~mm} \text { insulation }\end{array}$ & $\begin{array}{c}0.50 \ldots(0.70) \ldots 1.30 \\
0.12 \ldots 0.18\end{array}$ & $\begin{array}{l}0.25 \ldots 0.30 \\
0.13 \ldots 0.17\end{array}$ & $\begin{array}{l}0.04 \ldots 0.06 \\
0.04 \ldots 0.06\end{array}$ & $\begin{array}{l}0.13 \ldots 0.15 \\
0.09 \ldots 0.11\end{array}$ \\
\hline $\begin{array}{l}\text { External wall/ } \\
\text { internal wall }\end{array}$ & $\begin{array}{c}\text { Original/ } \\
+200 \mathrm{~mm} \text { insulation }\end{array}$ & $\begin{array}{c}0.12 \ldots(0.30) \ldots 1.10 \\
0.00 \ldots 0.02\end{array}$ & $\begin{array}{l}0.00 \ldots 0.03 \\
0.00 \ldots 0.01\end{array}$ & $\begin{array}{l}0.00 \ldots 0.02 \\
0.00 \ldots 0.01\end{array}$ & $\begin{array}{l}0.00 \ldots 0.02 \\
0.00 \ldots 0.01\end{array}$ \\
\hline $\begin{array}{l}\text { External walls/ } \\
\text { inserted ceiling }\end{array}$ & $\begin{array}{c}\text { Original/ } \\
+200 \mathrm{~mm} \text { insulation }\end{array}$ & $\begin{array}{c}0.25 \ldots(0.50) \ldots 0.70 \\
0.00 \ldots 0.03\end{array}$ & $\begin{array}{l}0.00 \ldots 0.02 \\
0.00 \ldots 0.01\end{array}$ & $\begin{array}{l}0.00 \ldots 0.02 \\
0.00 \ldots 0.01\end{array}$ & $\begin{array}{l}0.25 \ldots 0.35 \\
0.05 \ldots 0.07\end{array}$ \\
\hline $\begin{array}{l}\text { External walls/ } \\
\text { cellar ceiling }\end{array}$ & $\begin{array}{c}\text { Original/ } \\
+200 \mathrm{~mm} \text { insulation }\end{array}$ & $\begin{array}{c}0.25 \ldots(0.50) \ldots 0.70 \\
0.04 \ldots 0.06\end{array}$ & $\begin{array}{l}0.01 \ldots 0.03 \\
0.00 \ldots 0.02\end{array}$ & $\begin{array}{l}0.15 \ldots 0.20 \\
0.04 \ldots 0.08\end{array}$ & $\begin{array}{l}0.30 \ldots 0.40 \\
0.05 \ldots 0.07\end{array}$ \\
\hline $\begin{array}{l}\text { External walls/ inserted } \\
\text { ceiling at loggia or balcony }\end{array}$ & $\begin{array}{c}\text { Original/ } \\
+200 \mathrm{~mm} \text { insulation }\end{array}$ & $\begin{array}{l}0.15 \ldots(0.20) \ldots 0.65 \\
0.18 \ldots(0.30) \ldots 0.65\end{array}$ & $\begin{array}{l}0.01 \ldots 0.02 \\
0.10 \ldots 0.15\end{array}$ & Not typical & $\begin{array}{l}0.30 \ldots 0.35 \\
0.27 \ldots 0.33\end{array}$ \\
\hline $\begin{array}{l}\text { External wall/ } \\
\text { pitched roof }\end{array}$ & $\begin{array}{c}\text { Original/ } \\
+200 \mathrm{~mm} \text { insulation }\end{array}$ & $\begin{array}{c}0.40 \ldots(0.55) \ldots 1.0 \\
0.20 \ldots 0.55\end{array}$ & $\begin{array}{l}0.30 \ldots 0.60 \\
0.40 \ldots 0.50\end{array}$ & $\begin{array}{l}0.13 \ldots 0.17 \\
0.11 \ldots 0.15\end{array}$ & $\begin{array}{l}0.25 \ldots 0.40 \\
0.09 \ldots 0.25\end{array}$ \\
\hline $\begin{array}{l}\text { External wall/ } \\
\text { flat roof with parapet }\end{array}$ & $\begin{array}{c}\text { Original/ } \\
+200 \mathrm{~mm} \text { insulation }\end{array}$ & $\begin{array}{c}0.20 \ldots(0.25) \ldots 0.90 \\
0.17 \ldots 0.50\end{array}$ & $\begin{array}{l}0.25 \ldots 0.50 \\
0.20 \ldots 0.25\end{array}$ & Not typical & Not typical \\
\hline $\begin{array}{l}\text { External walls/ windows } \\
\text { (at original position) }\end{array}$ & $\begin{array}{c}\text { Original/ } \\
+200 \mathrm{~mm} \text { insulation }\end{array}$ & $\begin{array}{c}0.06 \ldots(0.13) \ldots 0.30 \\
0.20 \ldots 0.50\end{array}$ & $\begin{array}{l}0.35 \ldots 0.50 \\
0.35 \ldots 0.50\end{array}$ & $\begin{array}{l}0.00 \ldots 0.02 \\
0.01 \ldots 0.10\end{array}$ & $\begin{array}{l}0.06 \ldots 0.08 \\
0.12 \ldots 0.18\end{array}$ \\
\hline $\begin{array}{l}\text { External walls/ windows } \\
\text { (windows inside insulation) }\end{array}$ & $\begin{array}{c}\text { Original/ } \\
+200 \mathrm{~mm} \text { insulation }\end{array}$ & $\begin{array}{c}0.06 \ldots(0.13) \ldots 0.30 \\
0.01 \ldots 0.03\end{array}$ & $\begin{array}{l}0.35 \ldots 0.50 \\
0.01 \ldots 0.04\end{array}$ & $\begin{array}{l}0.00 \ldots 0.02 \\
0.01 \ldots 0.10\end{array}$ & $\begin{array}{l}0.06 \ldots 0.08 \\
0.01 \ldots 0.05\end{array}$ \\
\hline
\end{tabular}
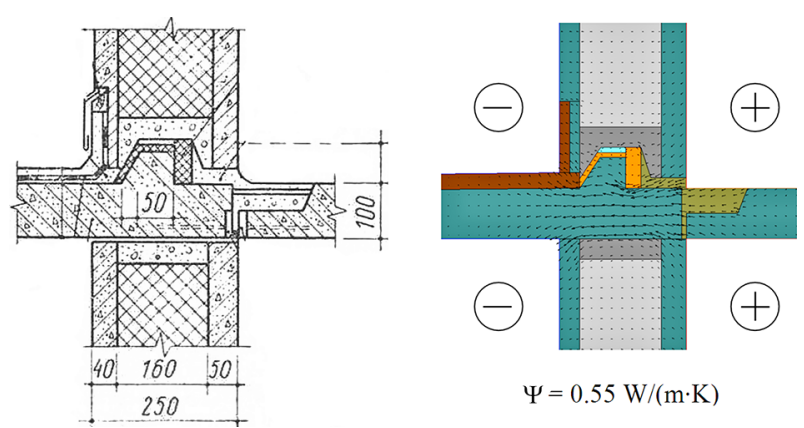

Fig. 6. Original drawing from the design documentation of the external wall/inserted ceiling at balcony junction (left) and heat flux vectors with the calculated linear thermal transmittance $\Psi$ (right)

\subsection{Calculation results}

Calculation results of linear thermal transmittances for four building types with varying junctions are shown in Table 2. Calculations were based on the original drawings of the buildings and information from the field survey. Results of calculations (values of the linear thermal transmittance $\Psi$ rounded to 0.01 if the value $\leq 0.20$ and rounded to 0.05 if the value $>0.20 \mathrm{~W} /(\mathrm{m} \cdot \mathrm{K}))$ are presented as a range instead of an average value. This approach was chosen because of variations and uncertainty at junctions caused by the variability of thermal properties, thickness of materials, constructional technology and other reasons. A calculation example with the best possible solution of an external wall/inserted ceiling at balcony is shown in Figure 6. At a wide range of values (e.g. concrete element buildings), also the third number in between is proposed, which can be considered as the most probable. Without any information available, that value can be used in the energy audit as the first approximation. At the external wall/roof junction both or only one can be insulated.

\section{Impact of thermal bridges}

Impact of thermal bridges on the thermal performance of a building can be taken into account separately, but for emphasis it is considered as a part of thermal transmittance of a wall. Relative significance of the thermal bridges of a typical five-storeyed concrete element apartment building (Fig. 1 left, and more detail in Ilomets and Kalamees (2013)) before the renovation is:

$$
\begin{aligned}
& U_{\text {red } .1}=U_{\text {original }}+\frac{\sum \Psi_{j} \cdot l_{j}}{A}= \\
& \frac{1}{0.13+0.11 / 2+0.14 / 0.16+0.04}+ \\
& \frac{43+163+166+64 / 2+26+58 / 2+6 / 2+189}{1091}= \\
& 0.91+0.60=1.51 \mathrm{~W} /\left(\mathrm{m}^{2} \mathrm{~K}\right)
\end{aligned}
$$

and after the renovation with $+200 \mathrm{~mm}$ insulation $(\lambda=0.04 \mathrm{~W} /(\mathrm{mK}))$ : 


$$
\begin{aligned}
& U_{\text {red.2 }}=U_{+200 \mathrm{~mm}}+\frac{\sum \Psi_{j} \cdot l_{j}}{A}= \\
& \frac{1}{0.13+0.11 / 2+0.14 / 0.16+0.2 / 0.04+0.04}+ \\
& \frac{7+6+6+4 / 2+46+22 / 2+4 / 2+442}{1091}= \\
& 0.16+0.48=0.64 \mathrm{~W} /\left(\mathrm{m}^{2} \mathrm{~K}\right) .
\end{aligned}
$$

The results obtained $-1.51 \mathrm{~W} /\left(\mathrm{m}^{2} \mathrm{~K}\right)$ before and $0.64 \mathrm{~W} /\left(\mathrm{m}^{2} \mathrm{~K}\right)$ after renovation indicate that thermal transmittance of a wall increases about $66 \%$ before and approximately three times after renovation derived from thermal bridges. Thus, the relative significance of thermal bridges in the transmission heat loss increases with an improved level of insulation. It must be noted here that only half of the linear thermal transmittance $\Psi$ was taken into account at the external wall/roof and the external wall/cellar ceiling junctions because the other half is the thermal transmittance related to the roof or the cellar ceiling, respectively. Results of $\Psi_{\mathrm{j}} l_{\mathrm{j}}$ in calculation of $U_{\text {red }}$ given above the line follow the order of junctions as presented in Table 2. Quantity $442 \mathrm{~W} / \mathrm{K}$ after renovation originates from external wall/window (and door) junction and it forms $85 \%$ of the transmission heat loss through all thermal bridges.

Figure 7 shows the impact of thermal bridges depending on the insulation thickness where the percentage of thermal bridges in the transmission heat loss of the building envelope is presented.

In typical bad practice renovation (Fig. 8, left) insufficient attention is paid to thermal bridges - windows are left to original position and concrete balcony slabs are not insulated during renovation (hereafter: bad practice). With best practice, windows are repositioned into additional thermal insulation (Fig. 8, right) and old concrete balcony slabs have been demolished and rebuilt (hereafter: best practice). In case of bad practice approach, percentage of thermal bridges in transmission heat loss increases with the level of additional insulation (Fig. 7), reaching up to $34 \%$ with typical insulation thickness $+200 \mathrm{~mm}$.

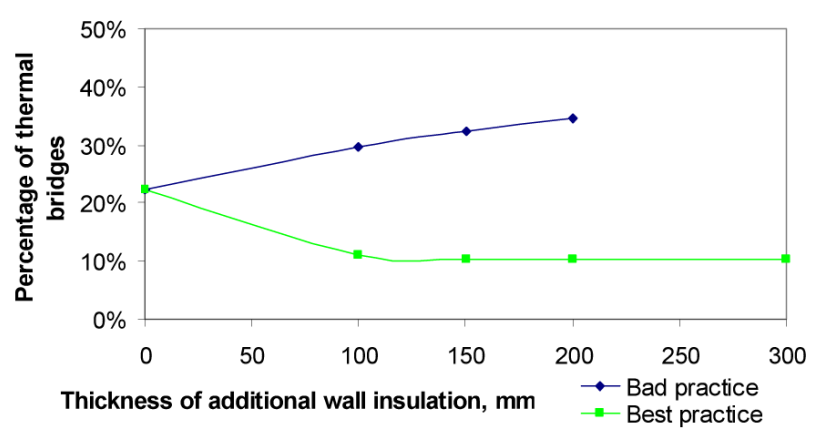

Fig. 7. Percentage of thermal bridges in transmission heat loss (through the whole building thermal envelope including thermal bridges)
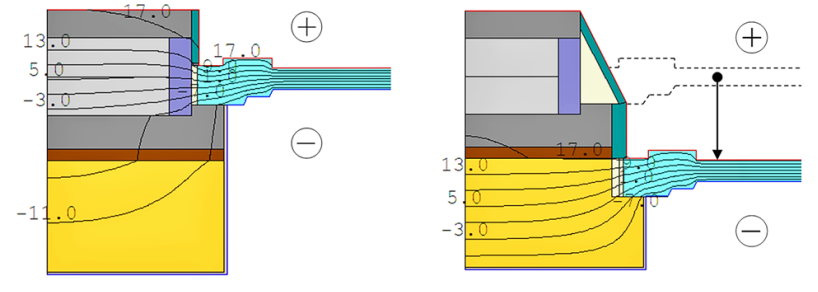

$\Psi=0.20 \ldots 0.50 \mathrm{~W} /(\mathrm{m} \cdot \mathrm{K})$
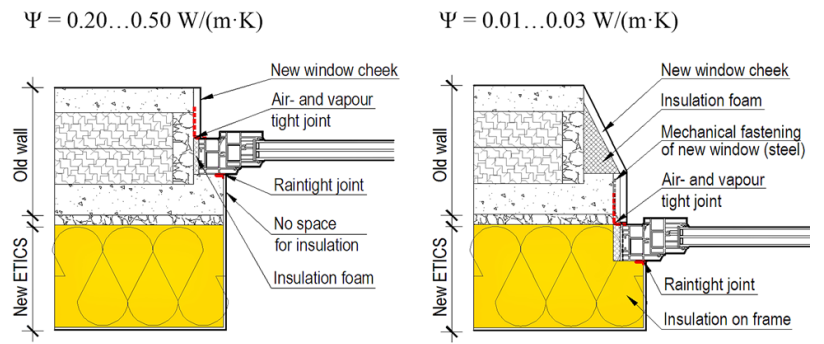

Fig. 8. Examples of bad practice (left) and best practice windows are repositioned into additional insulation (right). Isotherms in both cases are presented in upper row and designed principal renovation solution in bottom row

We also analysed the effect of thicker additional insulation of a wall required to compensate the impact of thermal bridges. In other words, how much extra wall insulation is needed to achieve equal linear thermal transmittance of the thermal bridges. In buildings renovated under bad practice, the external wall/window (numerous window perimeter length) and external wall/balcony junction have the largest impact on the thermal bridges. Theoretical thickness of additional wall insulation needed to compensate linear thermal transmittance of thermal bridges ends up at infinity at bad practice renovation if it is impossible to insulate the window jamb (also named window cheek), as was found in the analysis of our renovation case study (Ilomets, Kalamees 2013), see also Figure 8, bottom left. During best practice renovation where windows are repositioned and balconies rebuilt, additional insulation has to be $390 \mathrm{~mm}$ instead of $200 \mathrm{~mm}$ in order to compensate high thermal transmittance of thermal bridges.

\section{Discussion}

In this study we have evaluated the share of thermal bridges in the transmission heat loss of old apartment buildings based on Estonian example. As similar solutions were widely used in many parts of Eastern Europe and former Soviet Union with only few local changes made, results are useful also in other countries. Still, before using the values presented in this study, similarities and differences due to local typology, materials and workmanship practice related to junctions must be considered.

Both measurements and calculations show that the problem with thermal bridges is extremely serious especially for concrete element but also for brick buildings since constructional thermal bridges were already designed in original solutions. Most of the thermal bridges can be minimised by applying additional external ther- 
mal insulation and paying special attention to the external wall/window and the external wall/balcony junctions. As compared to concrete element buildings, the situation in brick buildings is somewhat better and in wooden and ACC buildings substantially better since there are fewer constructional joints (no in-situ concrete casting). Also, insulation is continuous at the external wall/internal wall and the external wall/inserted ceiling junctions in brick buildings.

Results of wooden apartment buildings indicate that the critical thermal bridge exists at the external wall/ foundation wall junction. Under renovation, the foundation wall should be additionally insulated from outside. Also, new windows with a similar width of a jamb should be carefully designed and installed with additional insulation during renovation.

In AAC buildings also critical thermal bridges exist, but the problem is somewhat less serious compared to concrete and brick buildings, mainly because of smaller thermal conductivity of the AAC blocks. Often in older apartment buildings, thermal bridge is a combination of a geometrical and a constructional thermal bridge.

Two main factors have worsened the situation related to thermal bridges during the last decade. First, inhabitants have replaced their windows, but usually a narrow $70 \mathrm{~mm}$ jamb is installed instead of an old wooden window with a wide jamb (ca $130 \mathrm{~mm}$ in wooden buildings and ca $95 \mathrm{~mm}$ in all other building types). Secondly, installation of additional external insulation with windows left at their original position has increased the linear thermal transmittance at the external wall/window junction. It must be emphasised that in addition to increased relative share of thermal bridges, also absolute value of linear thermal transmittance at external wall/window junction is increased after applying additional insulation.

Although the total thermal performance of a building during renovation is improved, we found that the relative percentage of thermal bridges increases with the thickness of insulation. From 23\% for a current state-ofthe-art building, we reached up to $34 \%$ with $+200 \mathrm{~mm}$ additional insulation during bad practice renovation as windows are the major source of the transmission heat loss. Large impact of thermal bridges can be emphasised by the ratio of linear thermal transmittances of the thermal bridges and the thermal transmittance of the walls, which results in a rate of 3 . This means that the heat flow rate from the heated space through the thermal bridges is three times larger than the heat flow rate of the opaque wall. The share of thermal bridges would have been even higher with a thicker layer of insulation, but insulation $>200 \mathrm{~mm}$ is not typical as windows kept to original position as bad practice. The same tendency (percentage of thermal bridges in the transmission heat loss is growing with the level of insulation) has been found in Berggren and Wall (2013). Our share of 34\% is in good correlation with $30-35 \%$ reported in Theodosiou and Papadopoulos (2008) and Erhorn et al. (2010). Also, Berggren and Wall (2013) found the impact between $20-38 \%$ for concrete element buildings - the same building type as used in our analysis. In addition, Kauppinen et al. (1997) found that thermal transmittance is valid only for $50 \%$ due to thermal bridges considering the heat loss of the whole building envelope and Al-Sanea and Zedan (2012) and Desjarlais and McGowan (1997) similarly claim that thermal resistance can be reduced twice by using internal dimensions of a building envelope.

The share of thermal bridges in the transmission heat loss of the building envelope after renovation depends strongly on the insulation on the window jamb under bad practice. This is caused by the large perimeter of the external wall/window junction. If the windows remain in their original position, the original linear thermal transmittance (up to $\Psi=0.30 \mathrm{~W} /(\mathrm{m} \cdot \mathrm{K})$ ) will increase (up to $\Psi=0.50 \mathrm{~W} /(\mathrm{m} \cdot \mathrm{K}))$ because of the insulation applied. Thermal performance of the external wall/window junction has been studied in Cappalletti et al. (2011) who reported a similar result - linear thermal transmittance up to $\Psi=0.40 \mathrm{~W} /(\mathrm{m} \cdot \mathrm{K})$ depending on the position of a window. Our renovation case-study analysis (Ilomets, Kalamees 2013) has shown that in practice it is impossible to sufficiently insulate a window jamb due to limited space (ca $10 \mathrm{~mm}$ ) for insulation. Unacceptably poor thermal performance of windows and balconies can be concluded by comparing the values of linear thermal transmittances presented in Table 2 and the results of Janssens et al. (2007). Limit value $\Psi=0.10 \mathrm{~W} /(\mathrm{m} \cdot \mathrm{K})$ is proposed to represent a sufficient level of linear thermal transmittance of junctions which is also supported by the default value in EN ISO 14683:2008 (2008). Since external dimensions of a building envelope were used in the referred sources, comparison is valid only for non-geometrical thermal bridges as junctions of the window and the balcony.

An impact as small as 10\% (Fig. 6) is achieved only by installing windows in a new position inside the additional insulation and removing existing concrete slab balconies. Since total transmission heat loss after renovation is already small, $10 \%$ of it means very small absolute quantity. Therefore, this solution can be suggested for sustainable complete best practice renovation and the share of $10 \%$ tends not to change with the thickness of insulation. In addition to the window junction, also the remaining external wall/balcony slab without thermal insulation can have a significant impact. Our study has found that the transmission heat loss of the building envelope rises by $5-9 \%$ when considering only the impact of old balconies. This is close to the result of $9-18 \%$ found by Ge et al. (2013).

Since the relative impact of thermal bridges enlarges with insulation thickness, focus during renovation should be on the minimisation of thermal bridges rather than on using thicker insulation to achieve the target, e.g. lowenergy level in cold climate. Minimising the effect of thermal bridges at the junctions of the building envelope in existing buildings is a major challenge and therefore careful design is essential. 
In addition to improved thermal performance, additional external thermal insulation improves thermal indoor environment and decreases the risk for mould growth in the corners because of higher surface temperature. New external insulation also protects the building envelope against climate loads and improves aesthetics.

\section{Conclusions}

Linear thermal bridges in the transmission heat loss were evaluated in four apartment building types - prefabricated reinforced concrete large-panel elements, bricks, wood $(\log )$, and autoclaved aerated concrete large-blocks. Range and typical values of the linear thermal transmittance of the thermal bridge (by using overall internal dimensions of a building envelope) was calculated for various junctions of four building types by using the 2D heat transfer simulation tool. Results are useful for many countries in Eastern Europe with similar non-renovated housing stock that are facing problems related to today's energy performance requirements.

Based on the thermography field measurements and calculations, we found that notable thermal bridges from the thermal performance aspect exist in all building types. The situation is the worst for concrete element buildings, where the linear thermal transmittance of the thermal bridge might be up to $\Psi=1.30 \mathrm{~W} /(\mathrm{m} \cdot \mathrm{K})$ as maximum and $\Psi=0.70 \mathrm{~W} /(\mathrm{m} \cdot \mathrm{K})$ as the most probable value to be used in the energy audit. Overlooking the external wall/ window and the external wall/balcony junctions as typical bad practice renovation, share of thermal bridges in the transmission heat loss of a building envelope is $30-34 \%$, depending on the thickness of additional insulation. Large linear thermal transmittance of the thermal bridges in certain junctions cannot be compensated with thicker insulation of the building envelope. As another extreme, share of thermal bridges in transmission heat loss might be only $10 \%$ in best practice.

In conclusion, windows have to be replaced (and repositioned into additional thermal insulation) and balconies should be rebuilt or insulated from top and bottom in order to fulfil energy performance requirements and to achieve, e.g. low-energy level. Linear thermal transmittance of the thermal bridges must be properly taken into account while conducting the energy audit or comparing the scenarios before the renovation.

\section{Acknowledgements}

This research was supported by the EU through the European Regional Development Fund. The research has been conducted as a result of the IUT1-15 project "Nearly-zero energy solutions and their implementation on deep renovation of buildings" (financed by the Estonian Research Council) and "Reducing the environmental impact of buildings through improvements of energy performance" (3.2.0801.11-0035, financed by SA Archimedes).

\section{References}

Al-Sanea, S. A.; Zedan, M. F. 2012. Effect of thermal bridges on transmission loads and thermal resistance of building walls under dynamic conditions, Applied Energy 98: 584593. http://dx.doi.org/10.1016/j.apenergy.2012.04.038

Asdrubali, F.; Baldinelli, G.; Bianchi, F. 2012. A quantitative methodology to evaluate thermal bridges in buildings, Applied Energy 97: 365-373. http://dx.doi.org/10.1016/j.apenergy.2011.12.054

Ben Larbi, A. 2005. Statistical modelling of heat transfer for thermal bridges of buildings, Energy and Buildings 37(9): 945-951. http://dx.doi.org/10.1016/j.enbuild.2004.12.013

Berggren, B.; Wall, M. 2013. Calculation of thermal bridges in (Nordic) building envelopes - risk of performance failure due to inconsistent use of methodology, Energy and Buildings 65: 331-339. http://dx.doi.org/10.1016/j.enbuild.2013.06.021

Biekša, D.; Šiupšinskas, G.; Martinaitis, V.; Jaraminienė, E. 2011. Energy efficiency challenges in multi-apartment building renovation in Lithuania, Journal of Civil Engineering and Management 17(4): 467-475. http://dx.doi.org/10.3846/13923730.2011.622408

Cappalletti, A.; Gasparella, A.; Romagnoni, P.; Baggio, P. 2011. Analysis of the influence of installation thermal bridges on windows performance: the case of clay block wall, Energy and Buildings 43(6): 1435-1442. http://dx.doi.org/10.1016/j.enbuild.2011.02.004

Capozzoli, A.; Gorrino, A.; Corrado, V. 2013. A building thermal bridges sensitivity analysis, Applied Energy 107: 229243. http://dx.doi.org/10.1016/j.apenergy.2013.02.045

Čiuprinskas, K.; Martinaitis, V. 2003. Correction of a designed building's heat balance according to its real heat consumption, Journal of Civil Engineering and Management 9(2): 98-103. http://dx.doi.org/10.1080/13923730.2003.10531311

Construction Products Regulation (EU) No 305/2011 of the European Parliament and of the Council repealing Council Directive 89/106/EEC [online], [cited 05 May 2014]. Available from Internet: http://eur-lex.europa.eu/legalcontent/EN/TXT/?uri=CELEX:32011R0305

Desjarlais, A.; McGowan, A. 1997. Comparison of experimental and analytical methods to evaluate thermal bridges in wall systems, in $3^{\text {rd }}$ ASTM Symposium on Insulation Materials: Testing and Applications, 15-17 May 1997, Quebec, Canada. Report No CONF-970582-2.

Déqué, F.; Ollivier, F.; Roux, J. J. 2001. Effect of 2D modelling of thermal bridges on the energy performance of buildings: numerical application on the Matisse apartment, Energy and Buildings 33(6): 583-587. http://dx.doi.org/10.1016/S0378-7788(00)00128-6

EN ISO 10211:2007 Thermal bridges in building constructionHeat flows and surface temperatures - Detailed calculations. European Committee for Standardization (CEN). Geneva, 2007. 45 p.

EN 13187:2001 Thermal performance of buildings - Qualitative detection of thermal irregularities in building envelopes - Infrared method. European Committee for Standardization (CEN). Geneva, 2001. 16 p.

EN ISO 13789:2008 Thermal performance of buildings - Transmission and ventilation heat transfer coefficients - Calculation method. European Committee for Standardization (CEN). Geneva, 2008. $18 \mathrm{p}$.

EN ISO 14683:2008 Thermal bridges in building construction - linear thermal transmittance - simplified methods and default values. European Committee for Standardization (CEN). Geneva, 2008. 23 p. 
EN ISO 6946:2007 Building components and building elements - Thermal resistance and thermal transmittance Calculation method. European Committee for Standardization (CEN). Geneva, 2007. 28 p.

EPBD Directive 2010/31/EU of the European Parliament and of the Council of 19 May 2010 on the energy performance of buildings, Official Journal of the European Union, 2010, L153/13-L153/35.

Erhorn, H.; Erhorn-Kluttig, H.; Citterio, M.; Cocco, M.; Orshoven, D.; Tilmans, A. 2010. An effective handling of thermal bridges in the EPBD context (ASIEPI report) 2010:69 [online], [cited 05 May 2014]. Available from Internet: http://www.buildup.eu/publications/8832

FLIR Systems 2006. FLIR ThermaCam E320 user's manual. Publ. No 1558407. 170 p.

Ge, H.; McClung, V. R.; Zhang, S. 2013. Impact of balcony thermal bridges on the overall thermal performance of multi-unit residential buildings: a case study, Energy and Buildings 60: 163-173. http://dx.doi.org/10.1016/j.enbuild.2013.01.004

Ignatavičius, Č.; Zavadskas, E.; Ustinovičius, L. 2007. Modernization of large-panel houses in Vilnius, in Proc. of the $9^{\text {th }}$ International Conference of Modern Building Materials, Structures and Techniques, 16-18 May 2007, Vilnius, Lithuania, 258-264.

Ilomets, S.; Kalamees, T. 2013. Case-study analysis on hygrothermal performance of ETICS on concrete wall after lowbudget energy-renovation, in Proceedings of XII International Conference on Performance of Exterior Envelopes of Whole Buildings, 2013, Florida, USA. ASHRAE. 14 p.

Janssens, A.; van Londersele, E.; Vandermarcke, B.; Roels, S.; Standaert, P.; Wouters, P. 2007. Development of limits for the linear thermal transmittance of thermal bridges in buildings, in Proceedings of Thermal Performance of the Exterior Envelopes of Whole Buildings X, 2007, Atlanta, GA, USA. American Society of Heating, Refrigerating and Air-Conditioning Engineers. $10 \mathrm{p}$.

Kauppinen, T.; Hyratt, J.; Sasi, L. 1997. Thermal performance of prefabricated multistory house in Tallinn, Estonia, based on IR survey, in Proceedings of Thermosense XIX, 4 April 1997, Orlando, USA. 12 p.

Lechtenböhmer, S.; Schüring, A. 2010. The potential for largescale savings from insulating residential buildings in the EU, Energy Efficiency 4(2): 257-270. http://dx.doi.org/10.1007/s12053-010-9090-6

Martin, K.; Campos-Celador, A.; Escudero, C.; Gomez, I.; Sala, J. M. 2012a. Analysis of a thermal bridge in a guarded hot box testing facility, Energy and Buildings 50: 139-149. http://dx.doi.org/10.1016/j.enbuild.2012.03.028

Martin, K.; Escudero, C.; Erkoreka, A.; Flores, I.; Sala, J. M. 2012 b. Equivalent wall method for dynamic characterisation of thermal bridges, Energy and Buildings 55: 704707. http://dx.doi.org/10.1016/j.enbuild.2012.08.024

Roels, S.; Deurinck, M.; Delghust, M.; Janssens, A.; van Orshoven, D. 2011. A pragmatic approach to incorporate the effect of thermal bridging within the EPBD-regulation, in Proceedings of $9^{\text {th }}$ Nordic Symposium on Building Physics (NSB 2011), 2011, Tampere, Finland, 1009-116.

Tilmans, A.; Orshoven, D. 2009. Software and atlases for evaluating thermal bridge. ASIEPI project 2009:10 [online], [cited 05 May 2014]. Available from Internet: http://www.buildup.eu/publications/5657

Theodosiou, T. G.; Papadopoulos, A. M. 2008. The impact of thermal bridges on the energy demand of buildings with double brick wall constructions, Energy and Buildings 40(11): 2083-2089. http://dx.doi.org/10.1016/j.enbuild.2008.06.006

Zavadskas, E. K.; Kaklauskas, A.; Gulbinas, A. 2004. Multiple criteria decision support web-based system for building refurbishment, Journal of Civil Engineering and Management 10(1): 77-85. http://dx.doi.org/10.1080/13923730.2004.9636289

Zavadskas, E. K.; Vilutienė, T.; Turskis, Z.; Šaparauskas, J. 2014. Multi-criteria analysis of projects' performance in construction, Archives of Civil and Mechanical Engineering 14(1): 114-121. http://dx.doi.org/10.1016/j.acme.2013.07.006

Simo ILOMETS. He is a researcher/teaching assistant in Chair of Building Physics and Energy Efficiency in Tallinn University of Technology. His research fields are building physics, durability and renovation of buildings. He has MSc in civil engineering. Currently his is a $\mathrm{PhD}$ candidate with a topic "The need for renovation of the building envelope of concrete apartment buildings".

Kalle KUUSK. He is a researcher in Chair of Building Physics and Energy Efficiency in Tallinn University of Technology. His research fields are building's service systems, indoor climate and energy performance of buildings. Currently his is a PhD candidate with a topic "Renovation of apartment buildings toward nearly zero energy buildings".

Leena PAAP. She is an engineer in Chair of Building Physics and Energy Efficiency in Tallinn University of Technology. Her research fields are building physics and renovation of buildings. She has MSc in civil engineering.

Endrik ARUMÄGI. He is a researcher in Chair of Building Physics and Energy Efficiency in Tallinn University of Technology. His research fields are indoor climate, hygrothermal and energy performance of historical buildings. Currently his is a PhD candidate with a topic "Sustainable renovation of historical buildings to provide better hygrothermal performance, energy efficiency and indoor climate".

Targo KALAMEES. He is the professor of Building Physics and head of Chair of Building Physics and Energy Efficiency in Tallinn University of Technology. His research fields are hygrothermal behaviour of buildings structures (computer simulations, laboratory experiments, field studies); boundary conditions for hygrothermal simulations and experiments; indoor climate and indoor air quality of residential-, office-, and heritage buildings; building's energy consumption and healthy building design; renovation of buildings. 